structure, tissue-distribution, and functions of tachykinins and their receptors. Curr Drug Targets 2006, 7, 963-974.

12) Satake H, Kawada T, Nomoto K, Minakata H. Insight into Tachykinin-Related Peptides, Their Receptors, and Invertebrate Tachykinins: A Review. Zoolog Sci 2003, 20, 533-549.

13) Pintado CO, Pinto FM, Pennefather JN, Hidalgo A, Baamonde A, Sanchez T, Candenas ML. A role for tachykinins in female mouse and rat reproductive function. Biol Reprod 2003, 69, 940-946.

14) Debeljuk L. Tachykinins and ovarian function in mammals. Peptides 2006, 27, 736-742.

15) Carnevali O, Cionna C, Tosti L, Lubzens E, Maradonna F. Role of cathep-sins in ovarian follicle growth and maturation. Gen Comp Endocrinol 2006, 146, 195-203.

16) Litscher ES, Qi H, Wassarman PM. Mouse zona pellucida glycoproteins $\mathrm{mZP} 2$ and mZP3 undergo carboxy-terminal proteolytic processing in growing oocyte. Biochemistry 1999, 38, 12280-12287.

17) Jakobsen RK, Ono S, Powers JC, DeLotto R. Fluorescently labeled inhibitors detect localized serine protease activities in Drosophila melanogaster pole cells, embryos, and ovarian egg chambers. Histochem Cell Biol 2005, 123, 51-60.

18) Sakairi K, Shirai H. Possible MIS production by follicle cells in spontaneous oocyte maturation of the ascidian, Halocynthia roretzi. Dev Growth Differ 1991, 33, 155-162.

19) Takagi-Sawada M, Someno T, Hoshi M, Sawada H. Inhibition of starfish oocyte maturation by leupeptin analogs, potent trypsin inhibitors. Dev Biol 1989, 133, 609-612.

20) Tanaka E, Takagi-Sawada M, Sawada H. Enzymatic properties of the protea-some purified from starfish oocytes and its catalytic subunits involved in oocyte maturation. Comp Biochem Physiol C Toxicol Pharmacol 2000, 125, 215-23.

21) Burighel P, Cloney RA. Urochordata ascidiacea. In: Harrison FW, ed. Microscopic anatomy of invertebrates. Vol. 15. New York: Wiley-Liss 1997, 221-347.

22) Prodon F, Chenevert J, Sardet C. Establishment of animal-vegetal polarity during maturation in ascidian oocytes. Dev Biol 2006, 290, 297-311.

23) McGuire NL, Bentley GE. Neuropeptides in the gonads: from evolution to pharmacology. Front Pharmacol. 2010, 1, 114.

\title{
軟骨魚類における尿素を用いた体液調節機構と その制御に関する研究
}

\author{
山口陽子 (東京大学大気海洋研究所 - 生理学分野) \\ (現所属: ハワイ大学海洋生物学研究所、博士研究員) \\ E-mail: proton@aori.u-tokyo.ac.jp
}

\section{1.はじめに}

生物が様々な環境に適応して生存していく 上で、体内の水分やイオンのバランスを制御 するしくみ、すなわち体液調節機構が必要不 可欠である。四肢動物や硬骨魚類は体液のイ オン組成および浸透圧を海水の約 $1 / 3$ に維持 している。これは体内の恒常性を維持する優 れた仕組みであるが、海生の種においては高 浸透圧環境による脱水の危機をもたらす。硬
骨魚真骨類の場合、大量の海水を飲んで水分 を補給し、過剩な塩分を鰓から排出すること で対処するが、これに対してサメやエイとい つた軟骨魚類は全く異なる戦略をとる。彼ら は体液中のイオン組成を海水の約半分に保つ 一方で、浸透圧調節物質として大量の窒素化 合物を蓄積している ${ }^{1,2)}$ 。その結果、体液浸 透圧は海水よりわずかに高張に保たれており、 海水中でも脱水されることなく体内に水分を 
保持することができる。

海生軟骨魚類においては、尿素が主要な浸 透圧調節物質であり、体液浸透圧の $1 / 3$ から 1/2を占める1,2)。そのため、体内の尿素濃度 を制御することは、軟骨魚類が海洋環境に適 応する上で、生理学的に最も重要な機構だと 言える。しかしながら硬骨魚類と比較して軟 骨魚類の研究は極女て遅れており、体液調節 機構に関する知見も断片的なものに留まって いた。私は博士課程において軟骨魚類の尿素 制御機構の全体像を明らかにすることを目的 とし、尿素を合成および保持するシステム、 さらにそれらの調節に関して研究を行った。

\section{2. 尿素再吸収系の変化：サメ腎臓における 尿素輸送体の動態}

体内に高濃度の尿素を保持するためには、 尿素を失わないしくみを持つことが重要であ る。尿素は鰓から漏出するほか、腎臓から尿 として環境中に排出されるが、損失を最小限 に抑えるため、軟骨魚類は特殊な仕組みを発 達させてきた。春椎動物の腎臓では、尿素を 含む血漿成分はいったん糸球体で濾過された

A

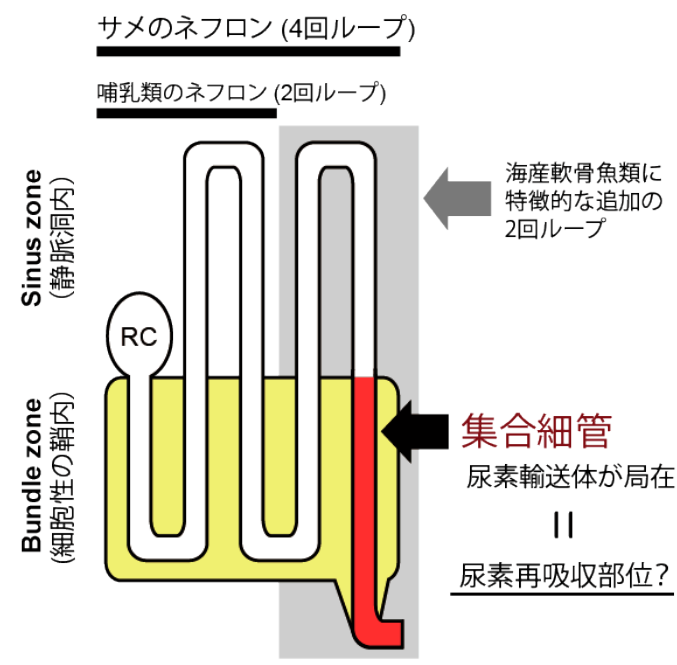

後、尿細管で必要に応じて再吸収される。哺 乳類の腎臓を構成する腎単位 (ネフロン) は ヘンレのループを含む2回ループ構造である が、海生軟骨魚類のネフロンは特殊な4回ル ープ構造をとり ${ }^{3,4)}$ 、濾過された尿素の90 $\%$ 以上を再吸収して体内に戻すことが知ら れている5, (図1)。私が所属する研究室で は、この回ループネフロンの最終分節であ る集合細管のみに尿素特異的な輸送体 (UT) が局在することを発見し、この分節が尿素再 吸収部位と予測していたが、その仕組みは 不明であった7)。そこで、ドチザメを異なる 塩分環境に移行することで人為的に体内尿素 濃度を変動させ、その際のUTの動態を解析 した。ドチザメを低濃度または高濃度海水に 移行すると、体内尿素濃度は外環境にあわせ て低下および上昇した。しかし、腎臓のUT mRNA量には実験群間で変化は見られなか った。一方、UTの染色性には明らかな差異 が認められた。そこで蛍光抗体と共焦点顕微 鏡を用いてUTのシグナルを半定量的に解析 すると、低濃度海水中ではシグナルが減少し、 特に管腔膜上のシグナルがほぼ消失した。こ
B
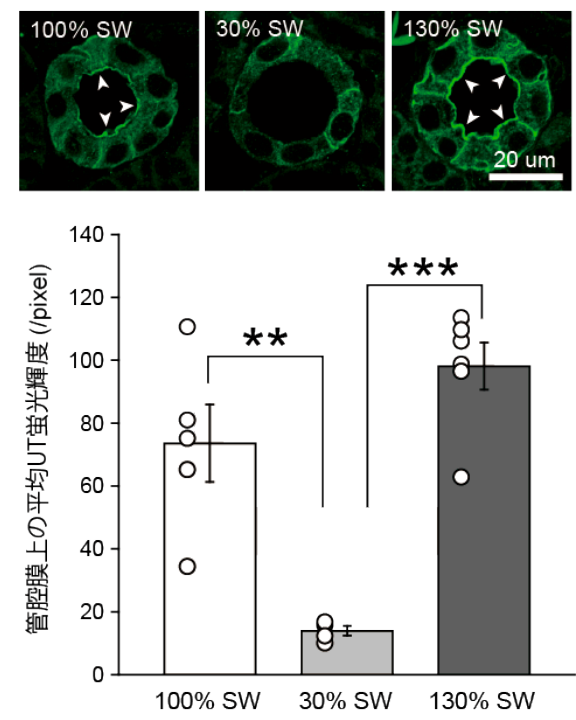

図1 軟骨魚類ネフロンの模式図 (A) および集合細管における尿素輸送体の膜局在变化 (B)

$\left({ }^{* *} \mathrm{P}<0.01\right.$ 、 ${ }^{* * *} \mathrm{P}<0.001$ 、Tukey-Kramer 検定による $)$ 
れに対して、高濃度海水中では管腔膜上のシ グナルは上昇傾向にあった (図1)。UTシグ ナルの変動が生理的に調節されているのか否 かを確かめるため、ドチザメを一旦低濃度海 水に馴致させてから通常海水に戻す実験を行 ったところ、戻し群では管腔膜上のUTシグ ナルはコントロール群と同じレベルまで回復 し、UTのシグナル強度は血中の尿素濃度と 高い相関を示した。これらの結果から、ドチ ザメの腎臓では、集合細管の管腔膜における UT 存在量が外環境浸透圧に依存して変化し、 尿素再吸収量を調節していることが示唆され た。

\section{3. 尿素合成系の変化 : 肝臓と筋肉における 尿素合成回路酵素の動態}

体内尿素濃度は合成と排出のバランスで 決まる。そこでドチザメの尿素調節機構を統 合的に理解するため、上記実験で使用した 同じ個体で尿素合成系の変動を調べた。尿 素は環境海水中にはほとんど存在しないが、 オルニチン尿素回路 (OUC) とよばれる一連 の酵素反応によって、生物体内でアンモニ アから合成される ${ }^{8)}$ 。哺乳類では肝臓が主要 な尿素産生部位であるが9）、魚類では近年、 肝臓以外の組織でもOUCの存在が示されて きた ${ }^{10 \sim 12)}$ 。そこでまず魚類 OUCの律速酵 素であるカルバミルリン酸合成酵素 (CPS) IIIについて、mRNAの組織分布をドチザメ で調べたところ、肝蔵だけでなく筋肉でも高 い発現が見られた。CPSIIIの酵素活性でも筋 肉は高い值を示し、個体あたりの組織重量を 考慮すると、尿素産生能は肝臓の3.6 17.3 倍と推定された。肝㵴では環境塩分変化に伴 う変動は見られなかったが、筋肉のCPSIII mRNAは低濃度海水中で減少し、血中尿素 濃度の変化と一致した(図2)。しかし、減少 した mRNA量は戻し移行実験でも回復しな かった。これらの結果はCPSIIIの酵素活性 でも同様であった。この原因として、戻し 移行実験のデザイン (実験期間の長さや、実 験中はサメに餌を与えないといつた条件)が、

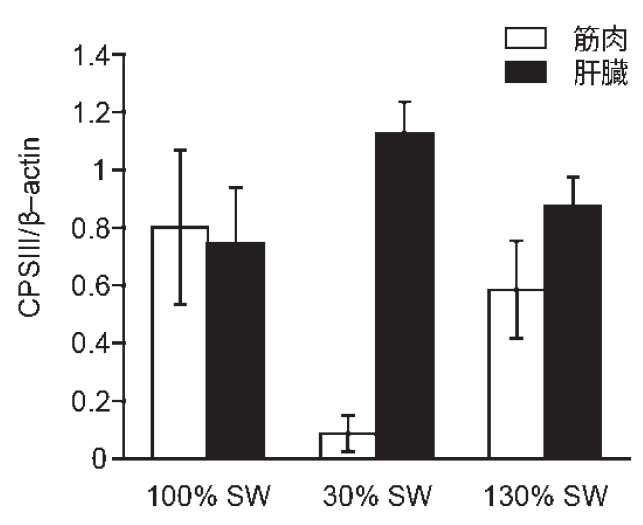

図2 筋肉および肝臓におけるCPSIII mRNAの発 現変化

尿素合成能を回復させるために十分ではな かった可能性を考えた。実際、戻し移行実験 では、血中尿素濃度はコントロール群の60 \%程度までしか回復していなかったからであ る。そこで、ドチザメに慨を与えながら長期 の戻し移行実験を行い、再度CPSIII mRNA と酵素活性を測定したが、やはりコントロー ルの水準には回復しなかった。一方で、筋肉 と肝蔵の両方で、OUCにアンモニアを取り 込むグルタミン合成酵素 (GS) の活性が上昇 し、尿素合成が促進されていることが示唆さ れた。以上の結果から、ドチザメでは筋肉が 主要な尿素産生部位であり、海水濃度変化に 伴って尿素産生量が調節されることがわかっ た。肝臓については、尿素合成量の基礎レ ベルを維持するのが主要な役割なのかもしれ ない。さらに本研究では、ドチザメの鰓にも CPSIII mRNAの発現が確認された。先行研 究から、軟骨魚類の鰓は尿素に加えてアンモ ニアの透過性も低いことが知られており、そ の理由として鰓での尿素産生の可能性が議 論されてきた ${ }^{13)}$ 。すなわち、鰓に存在する OUCがアンモニアをトラップして尿素に変 換し、体内に戻すという仮説であり、今回の 結果はこの仮説と一致するものであった。鰓 のCPSIII mRNA量は筋肉や肝臓と比較する と少ないため、体内尿素量を左右することは 考えにくい。しかし鰓の広大な表面積を考慮 すると、限られた窒素源を有効に活用して体 
内尿素濃度を維持するために、鰓が重要な役 割を果たすことは間違いないと思われる。

\section{4. 軟骨魚類神経葉ホルモン受容体の同定 : 新規受容体ファミリーの発見}

ここまで軟骨魚類の主要な浸透圧調節物質 である尿素の合成と再吸収について見てきた が、こうした尿素調節機構はどのような因子 によって制御されているのだろうか？よく知 られているように、脊椎動物のホメオスタシ スは様々なホルモンによって調節・維持され ている。本研究では、その中でも神経葉ホル モンに着目した。脊椎動物の神経葉ホルモン はその構造からバソプレシン属とオキシトシ ン属の 2 種類に大別され ${ }^{14,15) 、 こ の う ち ハ ゙ ソ ~}$ プレシン属は腎臓での水や各種イオンの再吸 収を促進する ${ }^{16)}$ 。加えて近年、哺乳類の腎 臓では、バソプレシンが尿素輸送体の膜局在 を制御することが報告されている ${ }^{17)}$ 。本研 究でもドチザメの血中バソトシン (バソプレ シンのホモログ) 濃度が外環境に応じて変動 し、腎臓における尿素輸送体の膜局在量と相 関を示した。このことから、神経葉ホルモン が軟骨魚類の尿素調節に関与する可能性を考 えた。

この仮説を検証するにあたって、神経葉ホ ルモンの受容体を同定し、尿素の合成や再吸 収に関わる様々な器官・部位での発現を調べ ることにした。春椎動物の神経葉ホルモンは 複数の異なる Gタンパク質共役型受容体を 介して多彩な機能を発揮する。これら受容体 の情報は、生体内でのホルモンの働きを理解 するのに必要不可欠であると同時に、軟骨魚 類の系統学的な位置づけ (現存する有顎脊椎 動物の中で最初期に分岐したグループ) を考 慮すると、神経葉ホルモン系の進化という観 点からも重要である。しかしながら、これま で軟骨魚類の受容体に関しては一切報告がな かった。そこで本研究では、軟骨魚類で唯 一、部分的ではあるがゲノムデータが公開さ れているゾウギンザメを研究モデルとして神 経葉ホルモン受容体のクローニングを行った。
なお、本項目の内容は General and Comparative Endocrinology誌に投稿したほか、昨年 の比較内分泌学会大会内のミニシンポジウム で発表する機会に恵まれた。今号の比較内分 泌学会誌に上記ミニシンポジウムに関する記 事を寄稿したので、詳細に関してはそちらを ご参照いただきたい。

先行研究から、春椎動物の神経葉ホルモ ン受容体には、V1aR、V1bR、V2Rおよ

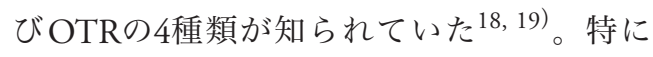
V2Rは四肢動物の腎臓で水やイオン、尿素の 再吸収に関わることが報告されているが、本 研究ではゾウギンザメゲノムから V $2 \mathrm{R} を$ 見 つけ出すことはできなかった。その代わり、 V2Rを除く3種類の受容体に加え、新規受容 体を発見した。新規受容体はV2Rに高い配 列相同性を示すものの、細胞内情報伝達には V2Rが用いる cAMPではなく、V1aRやV1bR と同様に $\mathrm{Ca}^{2+}$ 用いることがわかった。現 時点ではこの新規受容体をV $2 \mathrm{bR}$ 呼んでい る。ゲノムデータベース検索や分子系統解 析、シンテニー解析の結果、V $2 \mathrm{bR}$ が有顎脊 椎動物に広く存在すること、そしてV $2 \mathrm{bR} に$ 2つの異なるサブタイプ (魚類型と四肢動物 型）があることを見出した。V2bRの体内で の機能は今のところ不明だが、ゾウギンザメ V $2 b R$ は腎臓で発現することから、腎機能制 御に関わる可能性も考えられる。一方でゾウ ギンザメの下垂体では、四肢動物で ACTH 分泌に関わるV1bRに加えてV1aRも発現し ていた。V1aRが下垂体で発現する例はこれ までに報告がなく、バソトシンが下垂体にお いて未知の重要な機能を担う可能性がある。 以上の結果から、神経葉ホルモンが軟骨魚類 の体液調節に直接的または間接的に関与する 可能性が示唆された。同時に、新規受容体の 発見により、脊椎動物の神経葉ホルモン受容 体の進化に関する重要な知見が得られたが、 この点については上記の通り別記事に譲りた い。

なお、新規受容体については、上述の通り 機能解析やシンテニー解析を行い機能と進 
化をあわせて報告したが、残念ながら in silicoでの検索結果のみに基づく論文が先行して GCEに揭載され、初めての報告とはならな かつた ${ }^{20)}$ 。現時点で、新規受容体の命名は、 4 種類のバソプレシン /バソトシン受容体を 大きくV1型とV2型に分けるOcampo Daza et al. の方法にならっているが、今後さらに その進化を明らかにすることで、より良い命 名法が提唱されるかもしれない。

\section{5. まとめ}

本研究により、軟骨魚類の体内では、肝臓、 筋肉、腎臓、鰓といつた多くの器官が尿素の 合成や保持に関わり、それらが複雑に連携し て働くことで、環境に応じて体内尿素濃度を 高度に調節していることが明らかとなった (図3)。低濃度海水中ではドチザメ腎臓の集 合細管管腔膜上の尿素輸送体量が減少し、そ れに伴って尿素再吸収量が減少する。この時

筋肉：尿素合成

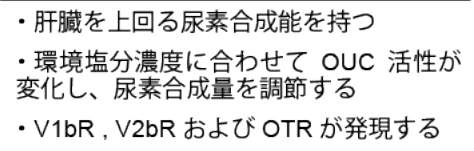

・肝臓を上回る尿素合成能を持つ 变化し、尿素合成量を調節する

・V1bR V V $\mathrm{bR}$ およひOTRか発現する

筋肉での尿素合成活性も低下するため、結果 として体内尿素濃度が低下する。逆に体内尿 素濃度を上昇させる場合も、合成系と再吸収 系が協調して働くことが分かった。ドチザメ を低濃度海水から再び通常海水に移行した場 合、腎臓では尿素輸送体の膜局在量が回復し、 それによって尿素再吸収量が回復する。筋肉 の尿素合成系では、律速酵素であるCPSIII の活性は回復しなかったが、そのほかの酵素 の活性が上昇することにより、尿素合成量は 増加するものと考えられる。また同時に、肝 臓での合成量が増加している可能性も示唆さ れた。本研究では、こうしたシステムの調節 因子として神経葉ホルモンに注目し、その受 容体を解析した。腎臓における尿素輸送体の 膜局在変化と神経葉ホルモンを結び付けると ころまでは至らなかったが、軟骨魚類が複数 の神経葉ホルモン受容体を持つこと、その中 には腎臓や筋肉、肝臓といった尿素調節器官

\section{腎臓: 尿素合成\&再吸収}

\section{- 集合細管管腔膜上の尿素輸送体量が環境塩分濃度 に従つて可逆的に変化し、尿素再吸収量を制御する ・アンモニアをグルタミンまたは尿素に変換して取 り込み、限られた窒素源を有効活用する \\ ・V2bR が発現する}

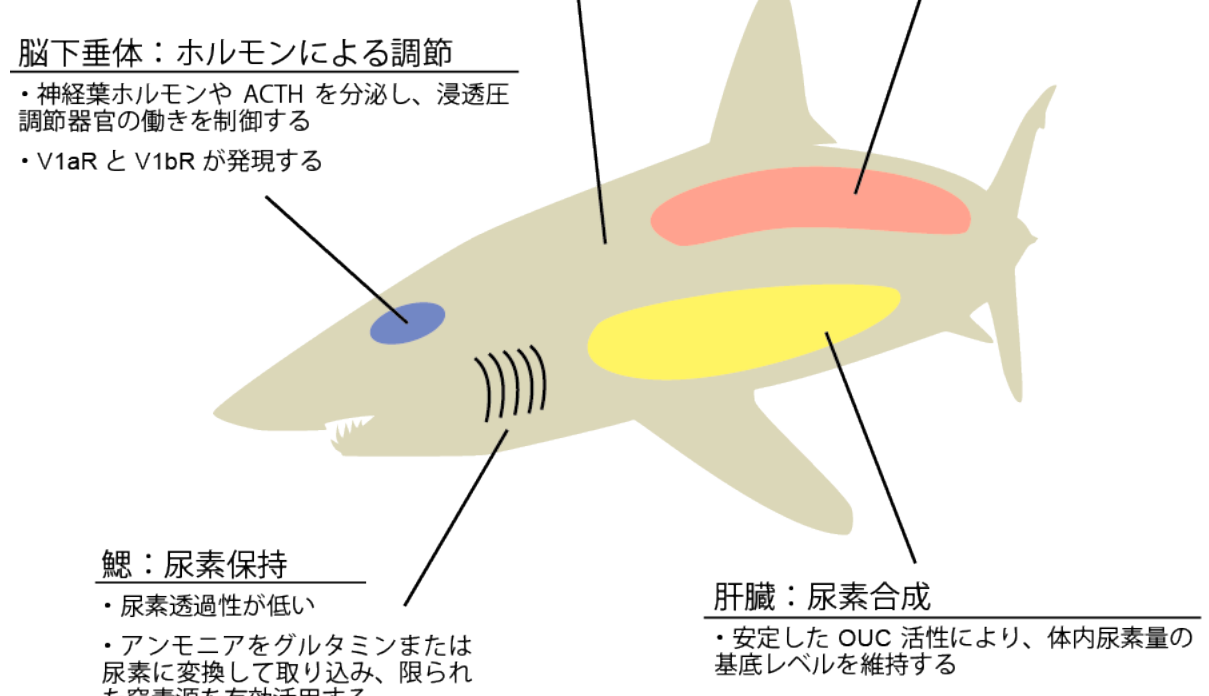

脳下垂体：ホルモンによる調節 調節器官の働きを制御する

・V1aR と V1bR が発現する 尿素に変換して取り込み、限られ た窒素源を有効活用する

図3 軟骨魚類の尿素制御機構の模式図 
に発現するものがあることが分かった。これ らの成果から、軟骨魚類においても他の奉椎 生物と同様、神経葉ホルモンが体液調節に重 要な役割を果たす可能性が示唆された。また、 研究を始めた当初は予想しなかったことだが、 本研究を通して春椎動物の新規バソプレシン 属受容体であるV $2 b R を$ 発見した。今後さら に解析を進めていくことで、この古典的なホ ルモンファミリーの軟骨魚類における機能を 解明すると同時に、これまで知られていなか つた未知の機能を明らかにすることができる と考えている。

\section{謝 辞}

修士課程と博士課程を通して、本研究の遂 行には多くの方々より多大なる御協力と御指 導を賜りました。特に、指導教員の兵藤晋准 教授をはじめとする研究室の先生方および皆 様、国立循環器病センター研究所の海谷啓之 博士、富山大学の今野紀文助教、岡山大学牛 空臨海実験所の御輿真穂助教、和歌山大学の 梶村麻紀子准教授に深く感謝致します。本研 究の一部は、東京大学グローバルCOE、東 京大学博士課程研究遂行協力制度、ならびに 財団法人日本科学協会の笹川科学研究助成に より御支援いただきました。最後に、本稿を 執筆する機会を与えて頂きました北里大学の 森山俊介教授に感謝申し上げます。

本研究の内容の一部は下記の通り投稿し、 公表しました。

Yamaguchi Y, Takaki S, Hyodo S (2009) Subcellular distribution of urea transporter in the collecting tubule of shark kidney is dependent on environmental salinity. J Exp Zool A 311: 705-718.

Yamaguchi Y, Kaiya H, Konno N, Iwata E, Miyazato $M$, Uchiyama M, Bell JD, Toop T, Donald JA, Brenner S, Venkatesh B, Hyodo S. (2012) The fifth neurohypophysial hormone receptor is structurally related to the V2-type receptor but functionally sim- ilar to V1-type receptors. Gen Comp Endocrinol, in press.

\section{文 献}

1) Hazon N, Wells A, Pillans RD, Good JP, Anderson WG, Franklin CE, 2003. Urea based osmoregulation and endocrine control in elasmobranch fish with special reference to euryhalinity. Comp Biochem Physiol B, 136, 685700.

2) Hammerschlag N, 2006. Osmoregulation in elasmobranchs; a review for fish biologists, behaviourists and ecologists. J Mar Freshw Behav Physiol, 39, 209-228.

3 ) Lacy ER, Reale E, 1985. The elasmobranch kidney II. Sequence and structure of the nephrons. Anat Embryol (Berl), 173, 163 186.

4 ) Hentschel H, Storb U, Teckhaus L, Elger M, 1998. The central vessel of the renal countercurrent bundles of two marine elasmobranchs - dogfish (Scyliorbinus caniculus) and skate (Raja erinacea) - as revealed by light and electron microscopy with computer-assisted reconstruction. Anat Embryol (Berl), 198, 73 89.

$5)$ Kempton RT, 1953. Studies of the elasmobranch kidney II. Reabsorption of urea by the smooth muscle of dogfish, Mustelis canis. Biol Bull, 104, 45-56.

6 ) Boylan JW, 1967. Gill permeability in Squalus acanthias. In: Gilbert PW, Mathewson RF, Rall DP (eds) Sharks, Skates and Rays. Baltimore, MD: Johns Hopkins Press. pp.197-206.

7 ) Hyodo S, Katoh F, Kaneko T, Takei Y, 2004. A facilitative urea transporter is localized in the renal collecting tubule of the dogfish Triakis scyllia. J Exp Biol, 207, 347-356.

8 ) Krebs HA, Henseleit K, 1932. Studies on urea formation in the animal organism. Hoppe Seylers Z Physiol Chem, 210, 33-66.

9 ) Morris SM Jr, 2002. Regulation of enzymes of the urea cycle and arginine metabolism. Annu Rev Nutr, 22, 87-105.

10) Tam WL, Wong WP, Loong AM, Hiong KC, Chew SF, Ballantyme JS, Ip YK, 2003. The osmotic response of the Asian freshwater stingray (Himantura signifer) to increased salinity: A comparison with marine (Potamotrygon motoro) stingrays. J Exp Biol, 206, 29312940. 
11) Steele SL, Yancey PH, Wright PA, 2005. The little skate Raja erinacea exhibits an extrahepatic ornithine urea cycle in the muscle and modulates nitrogen metabolism during lowsalinity challenge. Physiol Biochem Zool, 78, 216-226.

12) Kajimura M, Walsh PJ, Mommsen TP, Wood CM, 2006. The dogfish shark (Squalus acanthias) increases both hepatic and extrahepatic ornithine urea cycle enzyme activities for nitrogen conservation after feeding. Physiol Biochem Zool, 79, 603-613.

13) Wood CM, Pärt P, Wright PA, 1995. Ammonia and urea metabolism in relation to gill function and acid-base balance in a marine elasmobranch, the spiny dogfish (Squalus acanthias). J Exp Biol, 198, 1545-1558.

14) Urano A, Hyodo S, Suzuki M, 1992. Molecular evolution of neurohypophysial hormone precursors. Prog Brain Res, 92, 39-46.

15) Acher R, 1996. Molecular evolution of fish neurohypophysial hormones: neutral and selective evolutionary mechanisms. Gen Comp Endocrinol, 102, 157-172.
16) Nielsen $S$, Chou CL, Marples D, Christensen EI, Kishore BK, Knepper MA, 1995. Vasopressin increases water permeability of kidney collecting duct by inducing translocation of aquaporin-CD water channels to plasma membrane. Proc Natl Acad Sci USA, 92, 1013-1017.

17) Klein JD, Fröhlich O, Blount MA, Martin CF, Smith TD, Sands JM, 2006. Vasopressin increases plasma membrane accumulation of urea transporter UT-A1 in rat inner medullary collecting ducts. J Am Soc Nephrol, 17, 26802686.

18) Birnbaumer $M, 2000$. Vasopressin receptors. Trends Endocrinol Metab, 11, 406-410.

19) Gimpl G, Fahrenholz F, 2001. The oxytocin receptor system: structure, function, and regulation. Physiol Rev, 81, 629-683.

20) Ocampo Daza D, Lewicka M, Larhammar D, 2012. The oxytocin/vasopressin receptor family has at least five members in the gnathostome lineage, inclucing two distinct V2 subtypes. Gen Comp Endocrinol, 175, 135143. 